\title{
The Private Fund Limited Partnership: A New Fund Vehicle for the UK
}

Purpose: To explain the UK government's long-awaited reforms to limited partnership law.

Design/methodology/approach: This article discussed the key updates to limited partnership law in the UK that the reforms represent, and draws some conclusions as to what may lay ahead.

Findings: This article concludes that the new regime is a welcome step and one that should help the United Kingdom to remain competitive as a jurisdiction for global fund formation in the face of competition from other jurisdictions.

Originality/ value: This article contains key details on the new limited partnership regime in the UK.

Keywords: Private Funds, Limited Partnerships, Regulatory

Article Classification: Technical paper

On 6 April 2017, the UK government's long-awaited reforms to limited partnership law became effective. The effect of the changes is to create a new UK vehicle for private funds.

The Legislative Reform (Private Fund Limited Partnerships) Order 2017 (the "Reform Order") establishes a new fund vehicle known as a Private Fund Limited Partnership ("PFLP"). The PFLP was born of the UK government's desire to ensure the continuing competitiveness of English and Scottish limited partnerships as private fund vehicles with a focus on reducing administrative burdens and increasing flexibility to accommodate the ever-evolving needs of fund sponsors and investors. The PFLP has the effect of broadening the types of investment strategy for which UK limited partnerships may be appropriate.

Private fund sponsors commonly structure their funds as English or Scottish limited partnerships (referred to in this update as "UK limited partnerships"), regardless of the jurisdiction of the headquarters of the fund sponsor or the investment strategy and geographical focus of the fund. However, industry participants have long argued that some relatively small legal changes would enhance the attractiveness of the UK limited partnership. Despite many setbacks to the pace of reform including some last-minute fears that these changes would be further delayed - the Reform Order represents a welcome modernisation of the UK Limited Partnerships Act 1907 (the "LP Act"), the primary legislation governing UK limited partnerships. 


\section{DESIGNATION AS A PRIVATE FUND LIMITED PARTNERSHIP}

\section{New UK Limited Partnerships}

On registration of a UK limited partnership on or after 6 April, the general partner may elect for that UK limited partnership to be designated as a PFLP, provided the UK limited partnership satisfies the following conditions:

- it is constituted by written agreement; and

- it qualifies as a "collective investment scheme" under the Financial Services and Markets Act 2000 (or would do so but for an exemption).

\section{Existing UK Limited Partnerships}

It is important to note that the new PFLP regime is voluntary and the changes will not apply to an existing limited partnership unless the general partner elects for that limited partnership to opt in to the PFLP regime. If the general partner of an existing limited partnership wishes for that limited partnership to opt in to the PFLP regime, it will be important for the general partner to assess whether it is able unilaterally to make the optin determination or whether the limited partnership agreement mandates some degree of limited partner approval.

If you would like advice on whether to opt in to the PFLP regime (or, if you are an investor, whether to encourage your fund sponsors to opt in) or assistance with the process, please do not hesitate to contact us.

For both new and existing UK limited partnerships, once a limited partnership is designated as a PFLP, it is not possible for the general partner of that limited partnership to take the limited partnership out of the PFLP regime.

\section{PRINCIPAL CHANGES}

The principal changes introduced by the PFLP regime relate to:

- the introduction of a "white list" of activities that limited partners may undertake without running the risk of losing their limited liability status;

- the easing of restrictions regarding capital; and

- the removal of other administrative burdens.

\section{"WHITE LIST"}

The Reform Order introduces a non-exhaustive "white list" of activities that a limited partner of a PFLP may perform without jeopardising its limited liability status. The concept of a "white list" or "safe harbours" is one that is an important component of the 
limited partnership legislation that governs limited partnerships established in "popular" fund formation jurisdictions such as the Cayman Islands, Delaware, the Channel Islands and Luxembourg.

If a limited partner of a UK limited partnership takes part in the management of the partnership business, it will have unlimited liability for the debts of that limited partnership incurred while it takes part in the management. However, there is no authoritative guidance on what taking part in the management of the partnership business means. As a result, there has been a degree of uncertainty as to what a limited partner of a UK limited partnership may do without jeopardising its limited liability status.

In general, the "white list" clarifies that limited partners may play some role in relation to certain decisions in respect of a PFLP without jeopardising their limited liability status. The list is drafted broadly and covers activities such as approving or vetoing investments, as well as more mundane limited partner involvement (e.g., approving accounts, appointing or nominating a person to represent the limited partner on the private fund's advisory committee and taking part in a decision in respect of a potential or actual conflict of interest). The expectation is that the "white list" will make it much easier to utilise a UK limited partnership (that is a PFLP) for separate account arrangements. The list does not apply to circumstances where a limited partner represents, or purports to represent, the PFLP vis-à-vis third parties.

It is also important to note that the LP Act (now and post the Reform Order) does not prescribe rights that must be granted to limited partners. The rights of limited partners are dictated by the limited partnership agreement that governs the UK limited partnership. The Reform Order - through the "white list" grants flexibility for the crafting of a limited partnership agreement that reflects the commercial arrangements among the partners in a manner that protects the most fundamental aspect of a person's status as a limited partner (i.e., its limited liability status).

\section{CAPITAL CONTRIBUTIONS}

A limited partner in a PFLP is not required to contribute capital to that PFLP. Currently, a limited partner in a UK limited partnership must contribute capital on its admission as a limited partner in order to secure its limited liability status (i.e., capital must be drawn down from or advanced on behalf of a limited partner concurrently with its admission).

There is no restriction on a limited partner of a PFLP withdrawing capital contributed to that PFLP during the life of that PFLP. Currently, a limited partner of a UK limited partnership that withdraws capital contributed to that limited partnership during the life of that limited partnership will be liable for the debts of that limited partnership up to the amount of capital withdrawn. 
The current "capital" rules in respect of UK limited partnerships have led to the development of a market practice whereby a limited partner makes a de minimis capital contribution on admission as a limited partner, with the remainder of its commitment advanced to the UK limited partnership as interest-free loans. This market practice will no longer be relevant for a UK limited partnership that is designated as a PFLP.

\section{UK Limited Partnerships Registered after 6 April}

For a UK limited partnership registered after 6 April but which is designated as a PFLP after registration, any capital contributions made by a limited partner to that UK limited partnership (whether made before or after designation as a PFLP) may be withdrawn free from any obligation imposed by the LP Act to return that capital contribution.

\section{UK Limited Partnerships Registered before 6 April}

For a UK limited partnership registered before 6 April but which is designated as a PFLP, any capital contributions made by a limited partner to that UK limited partnership prior to designation as a PFLP will remain subject to the current "capital" rules (i.e., if any such capital contributions are withdrawn, the limited partner will be liable for the debts of the UK limited partnership up to the amount of capital withdrawn).

\section{OTHER ADMINISTRATIVE BURDENS}

The Reform Order introduces a simplified registration process for PFLPs, with a reduction in the amount of information that has to be included in an application for registration (or following a change in the particulars) when compared with what is currently required for a UK limited partnership. For example, the amount of a limited partner's capital contribution to a PFLP no longer needs to be notified to Companies House.

The Reform Order also abolishes the requirement under the LP Act to advertise publicly certain changes to a PFLP. The current requirement that an advertisement must be placed in the Gazette if, for example, a limited partner of a limited partnership assigns any portion of its interest in that limited partnership to another person, will not apply to a PFLP.

\section{GOING FORWARD}

The creation of the PFLP regime is a welcome step and one that should help the United Kingdom to remain competitive as a jurisdiction for global fund formation in the face of competition from other jurisdictions. Of course, Brexit will complicate the structuring question for fund sponsors in the years to come, but for those for whom a UK fund vehicle makes sense, the PFLP regime is bound to become the most popular route to take. 